Supplement of

\title{
A two-component parameterization of marine ice-nucleating particles based on seawater biology and sea spray aerosol measurements in the Mediterranean Sea
}

Jonathan V. Trueblood et al.

Correspondence to: Karine Sellegri (k.sellegri@opgc.cnrs.fr)

The copyright of individual parts of the supplement might differ from the article licence. 


\section{Theoretical Calculation of INP Normalized by SSA Surface Area}

3 For the purpose of the present study, surface area of SSA particles were calculated from the number size

4 distributions by assuming spherical particles. Theoretical calculation of the number and surface area distributions

5 for particles between .5-10 $\mu \mathrm{m}$ was also carried out. The fit from our observed number size distributions from

6 modes 1-4 agreed well with the fit of a sea spray aerosol source function consisting 5 lognormal modes based on in-situ particle number concentration measurements at Mace Head and open-ocean eddy correlation flux measurements from the Eastern Atlantic (Table S1) (Ovadnevaite et al., 2014). We took the ratio of mode 5 to mode 3 from this parameterization and applied it to our fit to calculate a fifth mode accounting for particles ranging in size between $500 \mathrm{~nm}$ and $10 \mu \mathrm{m}$. The resulting surface area distributions for each day are shown in Figure S1.

Table S1. Lognormal parameters for a sea spray source function parameterization from Ovadneveite et al. (2013) and for the fit of observed particle counts during the PEACETIME cruise. For each mode (i), a geometric standard deviation $\left(\sigma_{i}\right)$, count-median diameter $\left(C M D_{i}\right)$, and total number flux $\left(F_{i}\right)$ or amplitude is shown. For the fit from the literature (Ovadnevaite et al., 2014). $F_{i}$ is a function of Reynolds number $R_{H w}$ which we selected as $3.1 \times 10^{6}$ based on the air flow across the surface of the water in our bubbling apparatus.

\begin{tabular}{lccc}
\hline $\mathbf{i}$ & $\boldsymbol{\sigma}_{\mathbf{i}}$ & $\mathbf{C M D}_{\mathbf{i}}$ & $\mathbf{F}_{\mathbf{i}} / \mathbf{A m p l i t u d e}$ \\
\hline \multicolumn{3}{c}{ Ovadneveite et al. (2013) } \\
1 & 1.37 & 0.018 & $104.5\left(R e_{H w}-1 \times 10^{5}\right)^{0.556}$ \\
2 & 1.5 & 0.041 & $0.0442\left(R e_{H w}-1 \times 10^{5}\right)^{1.08}$ \\
3 & 1.42 & 0.09 & $149.6\left(R e_{H w}-1 \times 10^{5}\right)^{0.545}$ \\
4 & 1.53 & 0.23 & $2.96\left(R e_{H w}-1 \times 10^{5}\right)^{0.79}$ \\
5 & 1.85 & 0.83 & $0.51\left(R e_{H w}-1 \times 10^{5}\right)^{0.87}$ \\
& 1.5 & 0.01 & 0.01 \\
1 & 1.75 & 0.035 & 0.025 \\
2 & 1.7 & 0.115 & 0.031 \\
4 & 1.4 & 0.300 & 0.01 \\
\hline
\end{tabular}



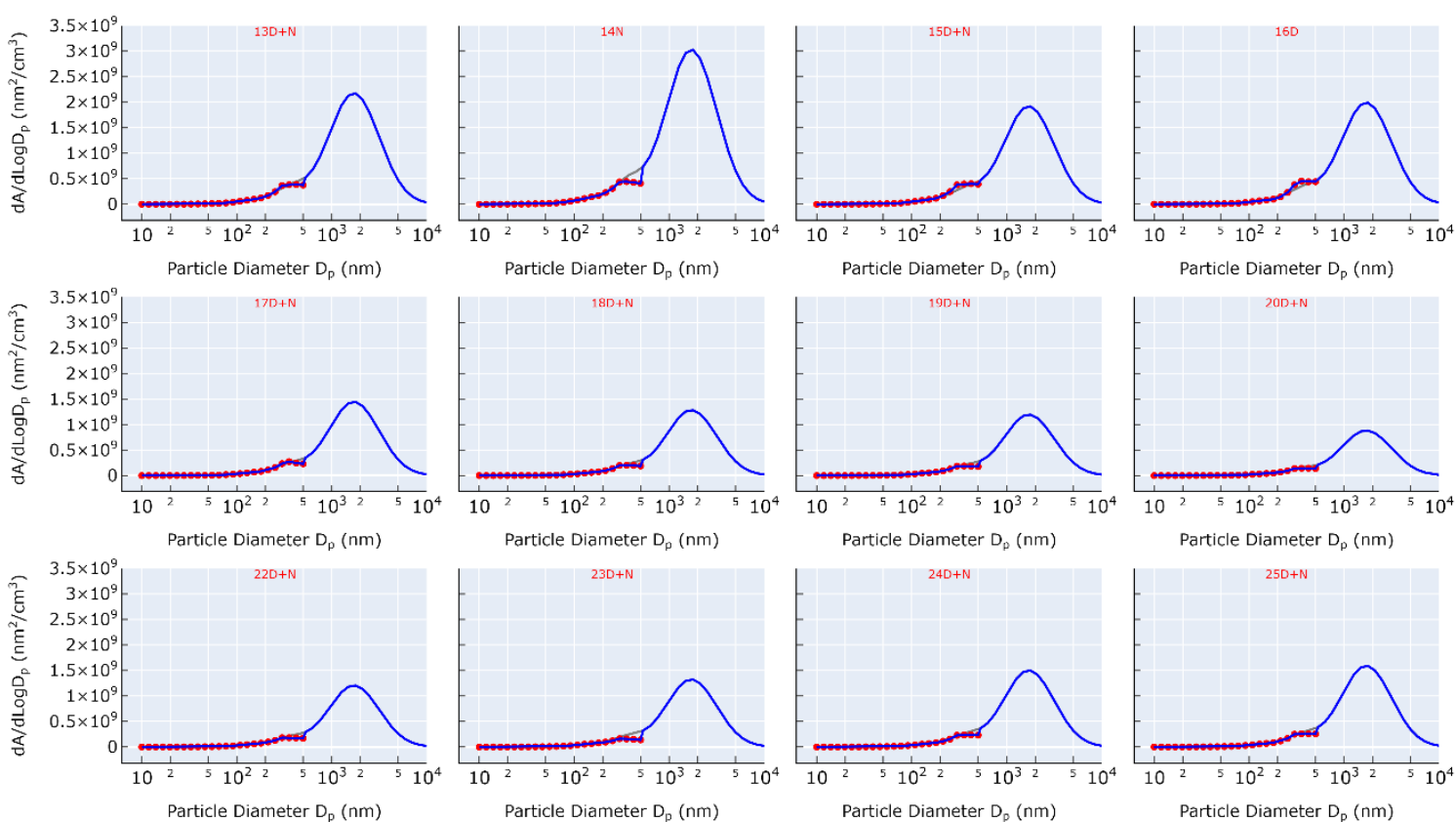

Diameter $\mathrm{D}_{\mathrm{p}}(\mathrm{nm})$

Particle Diameter $\mathrm{D}_{\mathrm{p}}(\mathrm{nm})$

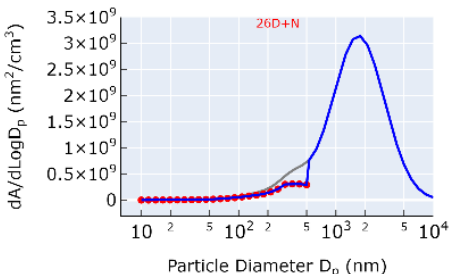

Particle Diameter $D_{p}(n m)$
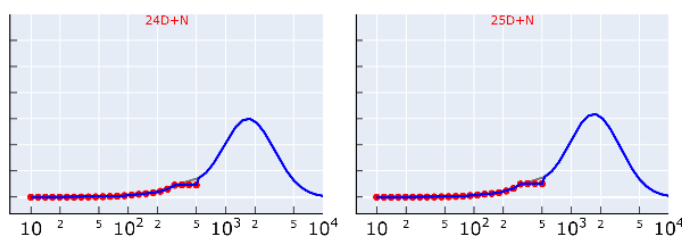

Particle Diameter $\mathrm{D}_{p}(\mathrm{~nm})$

Particle Diameter $D_{p}(n m)$
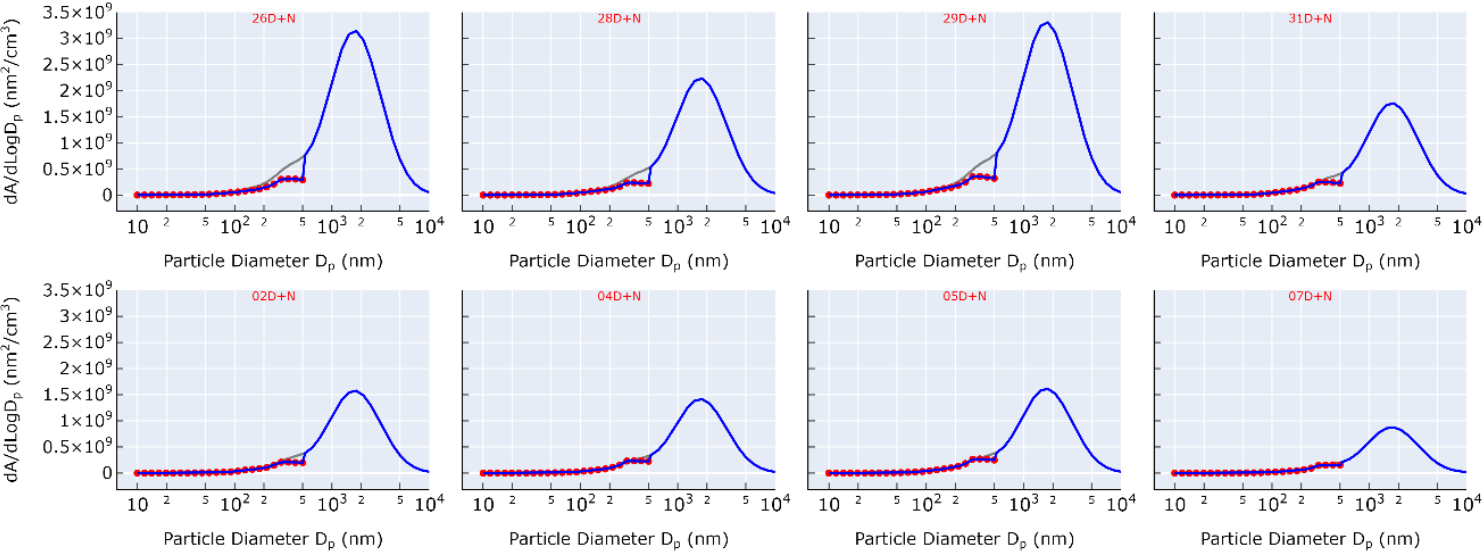

Particle Diameter $\mathrm{D}_{\mathrm{p}}(\mathrm{nm})$

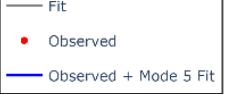

Figure S1. Daily average calculated surface area distributions.

Figure S2 compares the INP per $\mathrm{cm}^{2}$ of SSA surface during the PEACETIME cruise with values reported in previous studies. DeMott et al. (2016) reported INP concentrations from ambient measurements over the Caribbean, Arctic, Pacific, and Bering Sea. DeMott et al. (2016) and McCluskey et al. (2017) both reported INP concentrations from separate experiments in which SSA was artificially generated using nutrient-spiked seawater collected off the Scripps Institute of Oceanography (SIO) Pier with either a marine aerosol reference tank (MART) or an indoor waveflume. McCluskey et al. (2018a) reported ambient INP concentrations measured over the Southern Ocean. Finally, Gong et al. (2020) reported INP concentrations as measured off the coast of Cabo Verde. Our observed values are below those in all studies cited. The differences in our values compared to those in the literature can be attributed to a number of factors, including differences in trophic state of source waters, influences from terrestrial sources, and differences in INP analysis instruments. For example, Gong et al. (2020) state that most INPs observed in their study were from dust particles, rather than sea spray. Gong et al. (2020) also calculated a theoretical INP concentration based on the ratio of $\mathrm{NaCl}$ mass to INP in air and seawater (not shown in Figure 
$\mathrm{S} 2$ ). When we perform the same calculation using observed $\mathrm{NaCl}$ values in $\mathrm{SSA}$ and salinity measurements of underway seawater, we find that the INP/NaCl in the SSA is $\sim 3000$ times higher than in the SML. This is an important conclusion and points to the need for caution when using the Gong et al. (2020) approach for calculating a contribution of SSA-derived INP in ambient air aerosols in future studies. We note that studies in which seawater has been spiked with nutrients (McCluskey et al., 2017; McCluskey et al., 2018b; DeMott et al., 2016) are expected to have higher levels of biological activity than those observed in the Mediterranean and other oligotrophic regions. Since the departure of the PEACETIME INP in SML and SSW to the literature values is of the same order of magnitude as the departure of the PEACETIME INP in SSA to the literature, it is reasonable to attribute the low INPSSA values to the oligotrophic nature of the Mediterranean seawater.

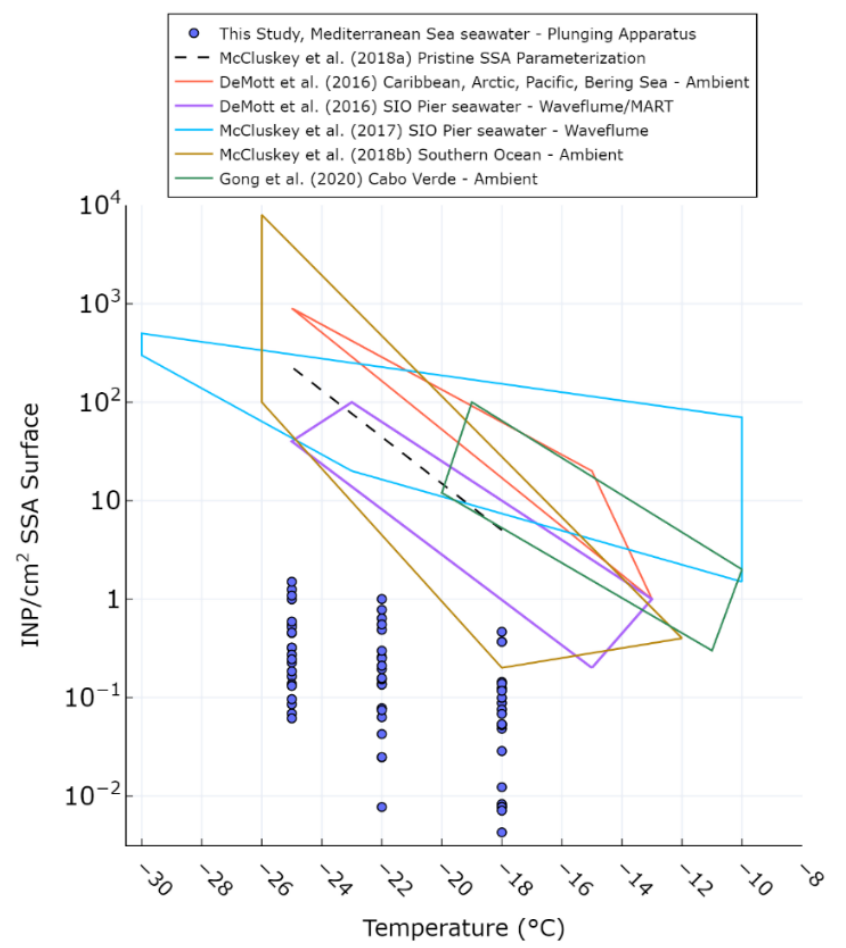

Figure S2. INP/cm ${ }^{2}$ SSA surface $\left(0.1<D_{p}<10 \mu \mathrm{m}\right)$ at various temperatures as measured by the DFPC during the PEACETIME cruise (blue circles) compared with values reported in the literature. SSA were generated by continuously passing seawater from the ship's underway system into a plunging apparatus. Error bars are not shown as the uncertainty is smaller than the data points. 

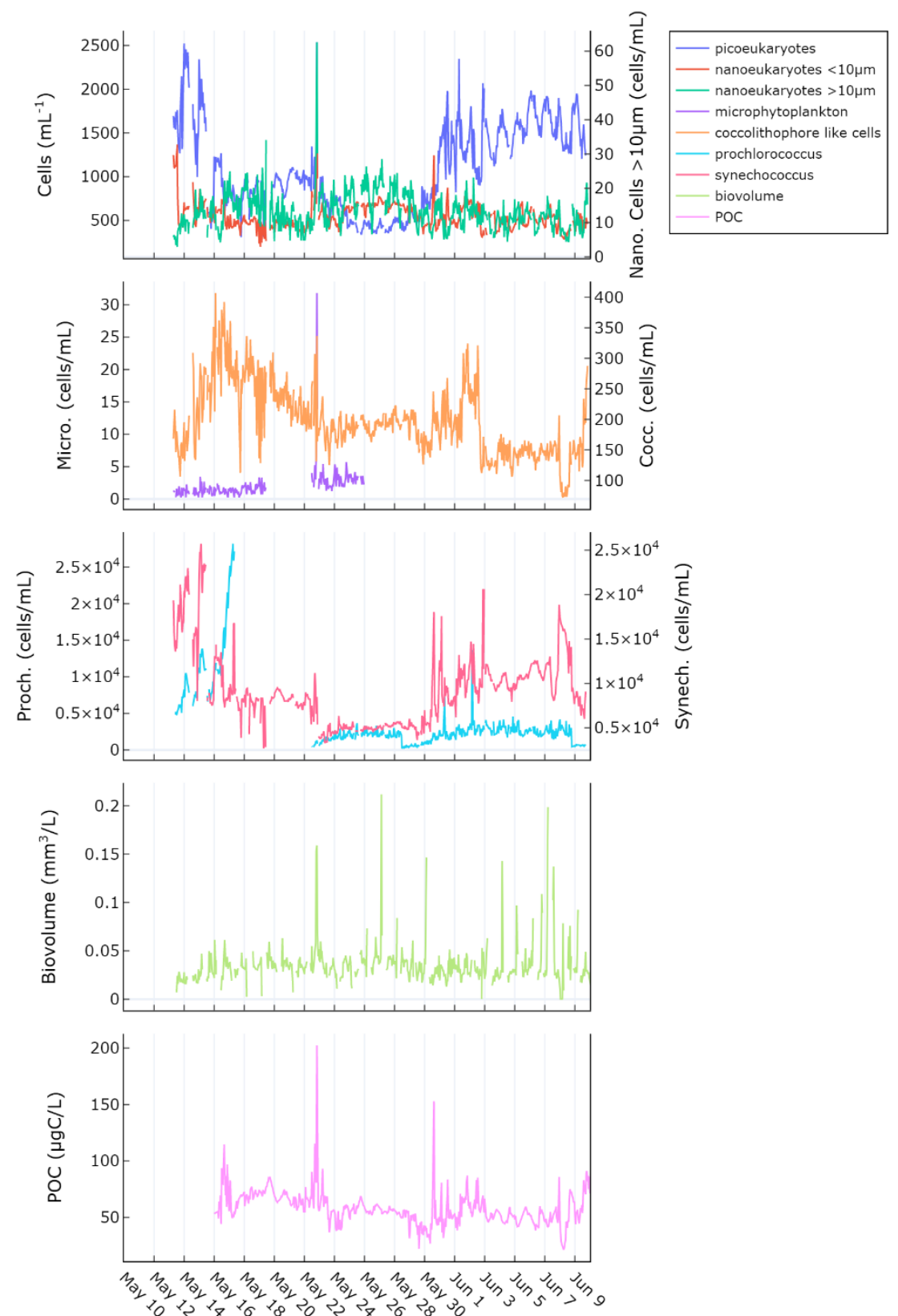

Day Number 

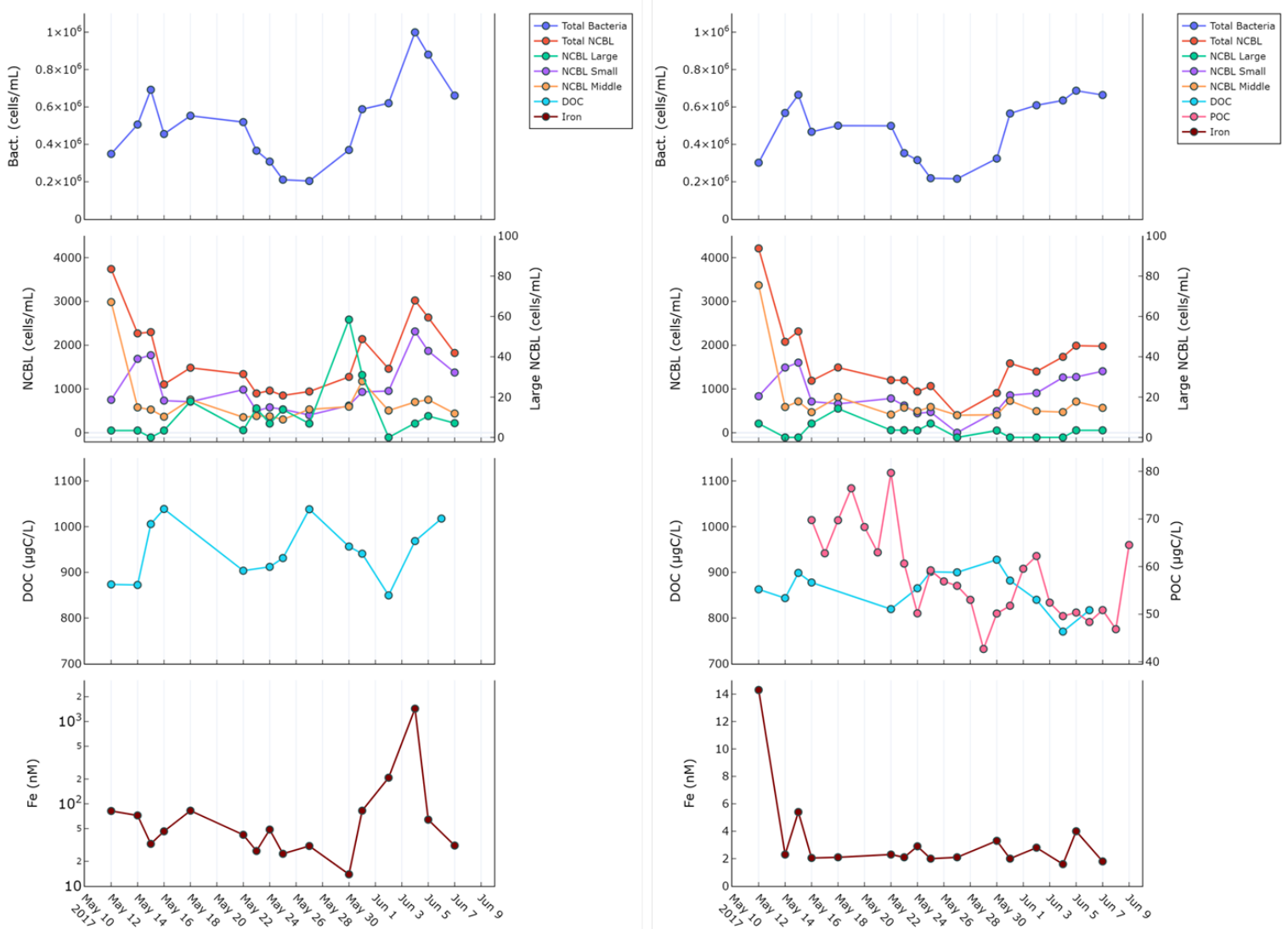

Day Number

Day Number

Figure S4. Various biogeochemical measurements in the SML (left) and SSW (right) as determined from the discrete seawater samples collected during pneumatic boat deployment. 

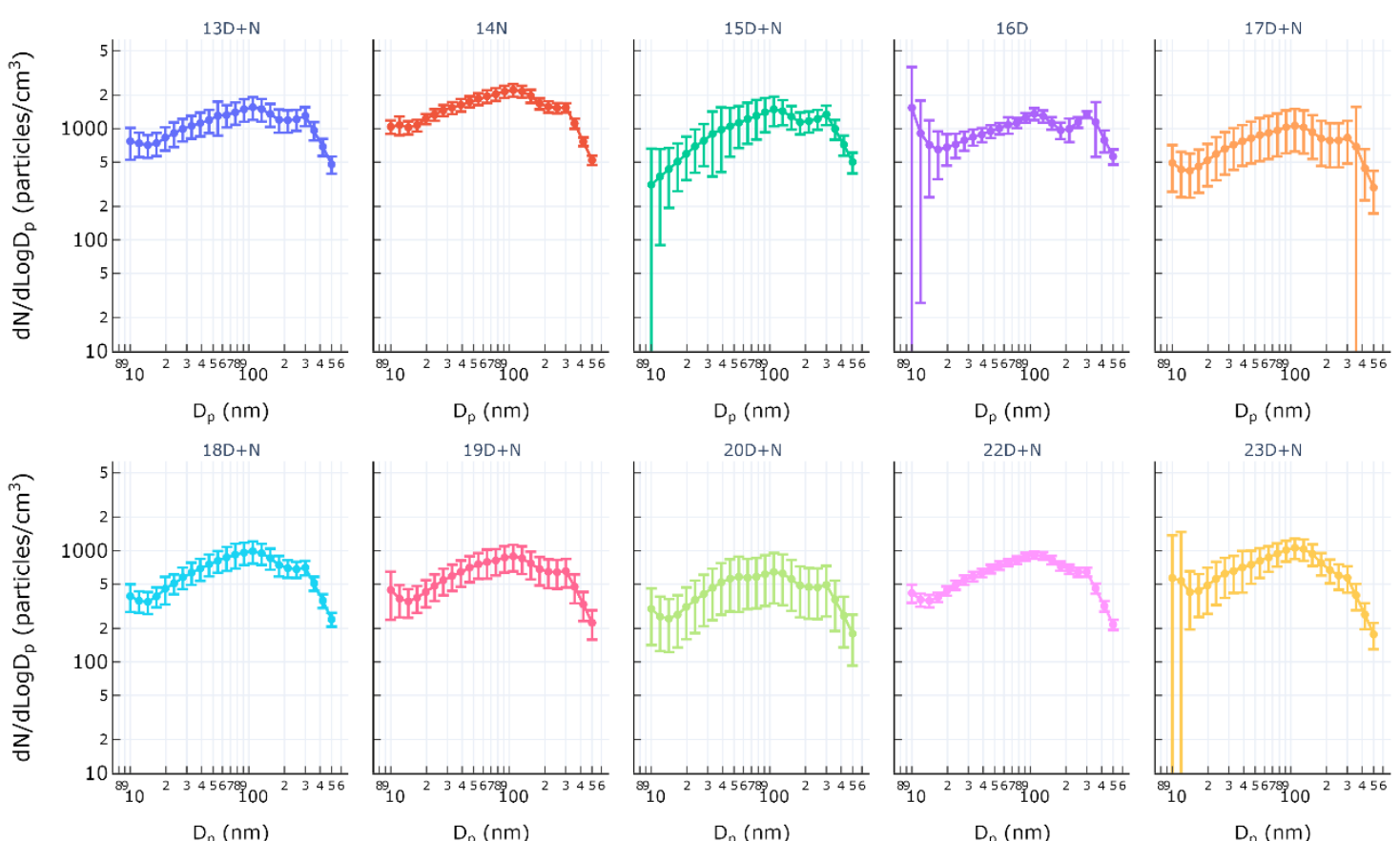

$D_{\mathrm{p}}(\mathrm{nm})$
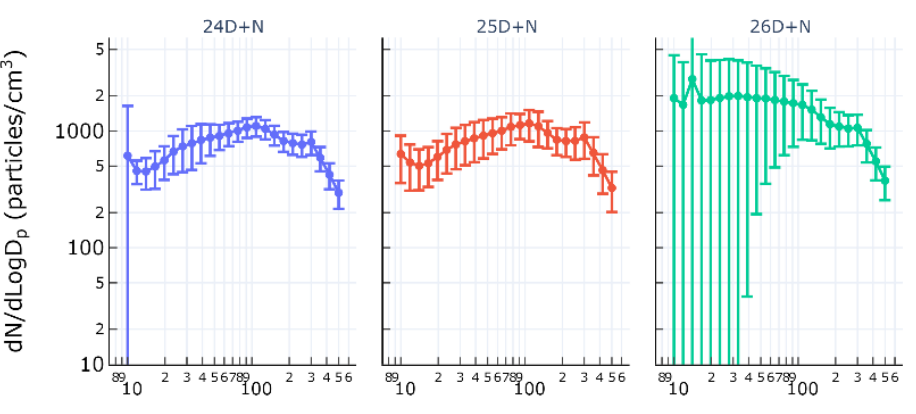

$\mathrm{D}_{\mathrm{p}}(\mathrm{nm})$

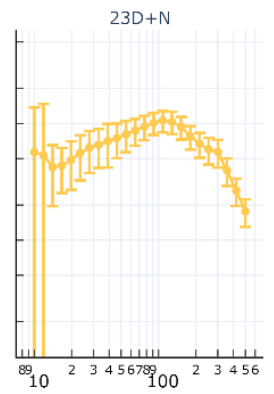

$D_{\mathrm{p}}(\mathrm{nm})$

$D_{\mathrm{p}}(\mathrm{nm})$

$D_{p}(n m)$

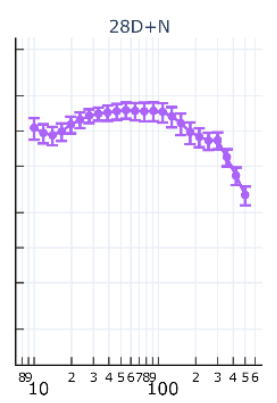

$D_{p}(n m)$
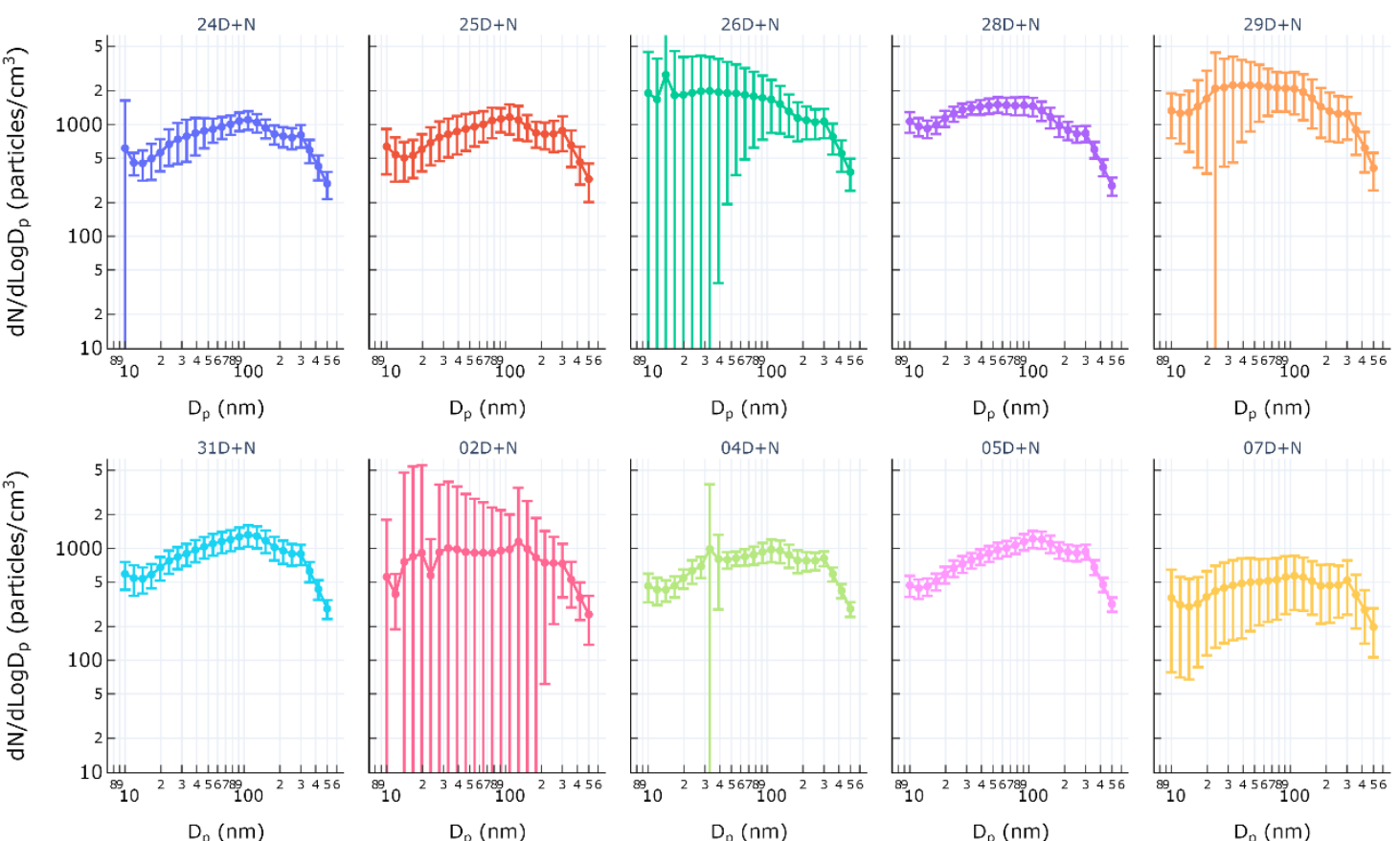

$D_{p}(\mathrm{~nm})$

$D_{p}(n m)$

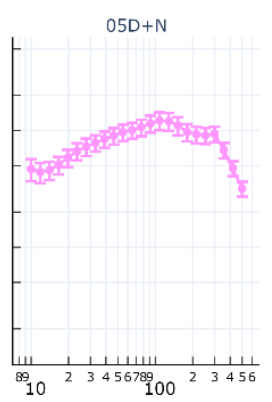

$D_{p}(n m)$

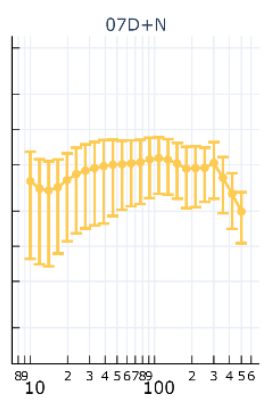

$D_{p}(n m)$

Figure S5. Average size distributions of SSA produced by the plunging apparatus as observed by DMPS across each DFPC sampling period. Error bars represent standard deviation. 


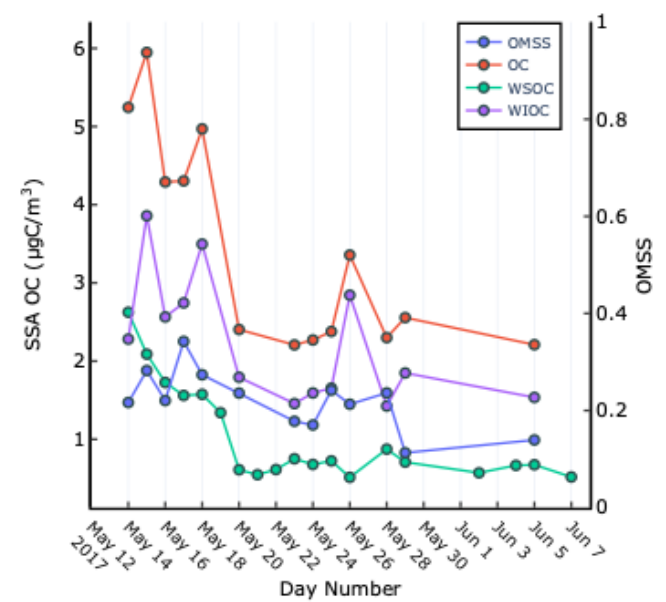

Figure S6. Organic content of artificially generated SSA using the plunging aquarium system continuously filled with seawater from the boat's underway system. SSA organic carbon concentration (OC) was greatest during the first part of the cruise, decreasing from $\sim 6 \mu \mathrm{gC} / \mathrm{m}^{3}$ (May 15), down to $\sim 2.5$ at FAST (June 5), except for a brief increase on May $26\left(3.6 \mu \mathrm{gC} / \mathrm{m}^{3}\right)$. The highest concentration of $\mathrm{OC}$ was concomitant with a bacteria abundance peak in SSW and SML bacteria and DOC (Figure S2). Interestingly, OC was not enhanced on June $5^{\text {th }}$ despite the enhanced seawater bacteria and DOC concentration around the same time (Figure S2). WIOC peaked on May $15\left(3.9 \mu \mathrm{gC} / \mathrm{m}^{3}\right)$, May $18(3.5$ $\left.\mu \mathrm{gC} / \mathrm{m}^{3}\right)$, and May $26\left(2.8 \mu \mathrm{gC} / \mathrm{m}^{3}\right)$. OMSS is defined as the organic mass fraction of submicron SSA.

\section{Model}

As explained in Section 4 of the main manuscript, we formulated various parameterizations consisting of different time periods, features, and number of components for temperature ranges. The details and goodness-of-fit values for each parameterization are shown below in Table S2.

\begin{tabular}{|c|c|c|c|c|c|c|c|c|}
\hline Model Name & $\begin{array}{l}\text { INP } \\
\text { Units }\end{array}$ & Days & $\begin{array}{c}\# \\
\text { Cat. }\end{array}$ & Features & $\begin{array}{c}\text { Warm } \\
\text { Features }\end{array}$ & $\begin{array}{c}\text { Cold } \\
\text { Features }\end{array}$ & $\mathbf{R}^{2}$ & $\mathbf{R}_{\mathrm{adj}}^{2}$ \\
\hline PD-2TC_OC_WIOC & $\mathrm{INP} / \mathrm{m}^{3}$ & Pre-Dust & 2 & & OCssa & WIOC & 0.66 & 0.63 \\
\hline PD-1TC_OC & $\mathrm{INP} / \mathrm{m}^{3}$ & Pre-Dust & 1 & OCssA & & & 0.63 & 0.61 \\
\hline PD-1TC_WSOC_WIOC & $\mathrm{INP} / \mathrm{m}^{3}$ & Pre-Dust & 1 & $\begin{array}{l}\text { WSOC, } \\
\text { WIOC }\end{array}$ & & & 0.64 & 0.60 \\
\hline AD-2TC_OC_WIOC & $\mathrm{INP} / \mathrm{m}^{3}$ & All Days & 2 & & OCssa & WIOC & 0.63 & 0.60 \\
\hline AD-T1C_OC & $\mathrm{INP} / \mathrm{m}^{3}$ & All Days & 1 & OCsSA & & & 0.61 & 0.59 \\
\hline PD-2TC_POC_PHYTO-L & $\mathrm{INP} / \mathrm{SSA}$ & Pre-Dust & 2 & & POCssw & $\begin{array}{l}\text { Micro- } \\
\text { NCBL }\end{array}$ & 0.62 & 0.59 \\
\hline AD-1TC_WSOC_WIOC & $\mathrm{INP} / \mathrm{m}^{3}$ & All Days & 1 & $\begin{array}{l}\text { WSOC, } \\
\text { WIOC }\end{array}$ & & & 0.62 & 0.58 \\
\hline PD-1TC_POC & INP/SSA & Pre-Dust & 1 & POCssw & & & 0.59 & 0.57 \\
\hline PD-1TC_POC_PHYTO-L & INP/SSA & Pre-Dust & 1 & $\begin{array}{l}\text { POC, Micro- } \\
\text { NCBL }\end{array}$ & & & 0.58 & 0.53 \\
\hline PD-2TC_WSOC_WIOC & $\mathrm{INP} / \mathrm{m}^{3}$ & Pre-Dust & 2 & & WSOC & WIOC & 0.53 & 0.49 \\
\hline AD-2TC_WSOC_WIOC & $\mathrm{INP} / \mathrm{m}^{3}$ & All Days & 2 & & WSOC & WIOC & 0.45 & 0.41 \\
\hline AD-1TC_POC & INP/SSA & All Days & 1 & POCssw & & & 0.43 & 0.40 \\
\hline AD-2TC_POC_PHYTO-L & INP/SSA & All Days & 2 & & POCssw & $\begin{array}{l}\text { Micro- } \\
\text { NCBL }\end{array}$ & 0.43 & 0.39 \\
\hline AD-2TC_POC_PHYTO-LM & $\mathrm{INP} / \mathrm{SSA}$ & All Days & 2 & & $\mathrm{POC}_{\text {ssw }}$ & $\begin{array}{l}\text { Micro- } \\
\text {,Nano- } \\
\text { NCBL }\end{array}$ & 0.43 & 0.38 \\
\hline
\end{tabular}


Similar to our approach with the W15 model described in Section 4 of the main text, we tested the MC18 model using the theoretical concentration of INP normalized by SSA surface area was conducted. Figure S7 shows observed vs predicted INPSSA for the MC18 parameterization. We see that MC18 overpredicts observed INP by two orders of magnitude. We also present re-calculated best-fit-lines to data using the same features as in MC18 (i.e., SSA surface area) in order to account for possible changes due to the oligotrophic nature of the Mediterranean Sea. We term this approach the altered McCluskey fit for oligotrophy, given as:

$$
\frac{I N P}{\mu m^{2}}=\exp (-26.57-(0.2782 * T))
$$

The result for this fit is shown in Figure S7 alongside the results of the original MC18 parameterization. The altered model offers an improvement over the original parameterization. The adjusted $\mathrm{R}^{2}$ was $\mathrm{R}_{\mathrm{adj}}{ }^{2}=0.32$ for the altered McCluskey fit for oligotrophy.

Figure S7. Parameterizations for prediction of INP in SSA at different temperatures using the MC18 method and refit with the same method using PEACETIME observations.

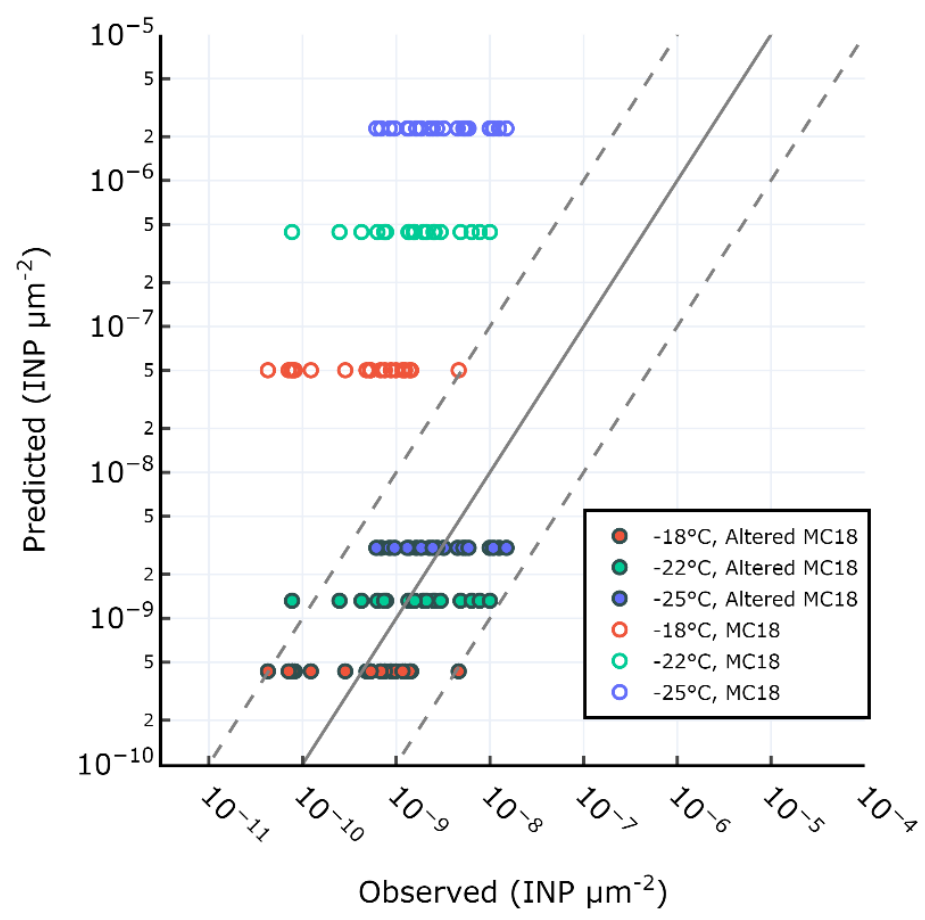




\section{References}

DeMott, P. J., Hill, T. C. J., McCluskey, C. S., Prather, K. A., Collins, D. B., Sullivan, R. C., Ruppel, M. J., Mason, R. H., Irish, V. E., Lee, T., Hwang, C. Y., Rhee, T. S., Snider, J. R., McMeeking, G. R., Dhaniyala, S., Lewis, E. R., Wentzell, J. J. B., Abbatt, J., Lee, C., Sultana, C. M., Ault, A. P., Axson, J. L., Martinez, M. D., Venero, I., Santos-Figueroa, G., Stokes, D. M., Deane, G. B., Mayol-Bracero, O. L., Grassian, V. H., Bertram, T. H., Bertram, A. K., Moffett, B. F., and Franc, G. D.: Sea Spray Aerosol as a Unique Source of ice Nucleating Particles, PNAS, 113, 5797-5803, https://doi.org/10.1073/pnas.1514034112, 2016.

Gong, X., Wex, H., van Pinxteren, M., Triesch, N., Fomba, K. W., Lubitz, J., Stolle, C., Robinson, T.-B., Müller, T., Herrmann, H., and Stratmann, F.: Characterization of aerosol particles at Cabo Verde close to sea level and at the cloud level - Part 2: Ice-nucleating particles in air, cloud and seawater, Atmospheric Chemistry and Physics, 20, 1451-1468, 10.5194/acp-20-1451-2020, 2020.

McCluskey, C. S., Hill, T. C. J., Malfatti, F., Sultana, C. M., Lee, C., Santander, M. V., Beall, C. M., Moore, K. A., Cornwell, G. C., Collins, D. B., Prather, K. A., Jayarathne, T., Stone, E. A., Azam, F., Kreidenweis, S. M., and DeMott, P. J.: A Dynamic Link between Ice Nucleating Particles Released in Nascent Sea Spray Aerosol and Oceanic Biological Activity during Two Mesocosm Experiments, J. Atmos. Sci., 74, 151-166, https://doi.org/10.1175/JAS-D-16-0087.1, 2017.

McCluskey, C. S., Hill, T. C. J., Humphries, R. S., Rauker, A. M., Moreau, S., Strutton, P. G., Chambers, S. D., Williams, A. G., McRobert, I., Ward, J., Keywood, M. D., Harnwell, J., Ponsonby, W., Loh, Z. M., Krummel, P. B., Protat, A., Kreidenweis, S. M., and DeMott, P. J.: Observations of Ice Nucleating Particles Over Southern Ocean Waters, Geophysical Research Letters, 45, 11,989-911,997, 10.1029/2018g1079981, $2018 \mathrm{a}$.

McCluskey, C. S., Hill, T. C. J., Sultana, C. M., Laksina, O., Trueblood, J. V., Santander, M. V., Beall, C. M., Michaud, J. M., Kreidenweis, S. M., Prather, K. A., Grassian, V. H., and DeMott, P. J.: A Mesocosm Double Feature: Insights into the Chemical Makeup of Marine Ice Nucleating Particles, J. Atmos. Sci., 75, 2405-2423, https://doi.org/10.1175/JAS-D-17-0155.1, 2018b.

Ovadnevaite, J., Manders, A., de Leeuw, G., Ceburnis, D., Monahan, C., Partanen, A. I., Korhonen, H., and O'Dowd, C. D.: A sea spray aerosol flux parameterization encapsulating wave state, Atmospheric Chemistry and Physics, 14, 1837-1852, 10.5194/acp-14-1837-2014, 2014. 